\title{
MEMAHAMI EKUITAS MEREK PERGURUAN TINGGI: PENELITIAN EMPIRIS PADA STIE SURAKARTA, JAWA TENGAH, INDONESIA
}

\author{
Elia Ardyan ${ }^{1 *}$, Wisnu Sancoyo ${ }^{1}$, Oky Tira Ayuda ${ }^{1}$, \\ Deni Setiadi ${ }^{1}$, Fenti Winda Sari ${ }^{1}$, Atika Ayu Ismawati ${ }^{1}$ \\ Novita Yuniarti ${ }^{1}$, Hafiz Kurniawan ${ }^{1}$, Winata ${ }^{1}$ \\ ${ }^{1}$ Program Studi Manajemen STIE Surakarta \\ Jalan Slamet Riyadi Makamhaji No. 435-436, \\ Sukoharjo 57141, Jawa Tengah, Indonesia \\ *Penulis korespondensi; E-Mail: ardyan.sbs@gmail.com
}

\begin{abstract}
Abstrak
Mengukur ekuitas merek menjadi bagian penting di dalam organisasi, khususnya perguruan tinggi. Dengan mengukur ekuitas merek, perguruan tinggi akan lebih memahami tentang kesadaran merek, asosiasi merek, persepsi kualitas, dan loyalitas merek suatu perguruan tinggi. Rumusan masalah penelitian adalah (1) bagaimana persepsi mahasiswa tentang kesadaran merek STIE Surakarta?; (2) bagaimana pengaruh asosiasi merek dan persepsi kualitas pada loyalitas merek. Penelitian ini dilakukan pada mahasiswa STIE Surakarta. Sampel penelitian ini adalah 120 mahasiswa STIE Surakarta. Analisis menggunakan analisis deskriptif dan Structural Equation Modeling (SEM). Hasil penelitian ini menunjukkan bahwa (1) merek STIE Surakarta menempati posisi ke-3 di benak konsumen; (2) asosiasi merek memiliki pengaruh positif tetapi tidak signifikan pada loyalitas merek dan persepsi kualitas memiliki pengaruh positif dan signifikan pada loyalitas merek.
\end{abstract}

Kata kunci: Ekuitas merek, kesadaran merek, asosiasi merek, persepsi kualitas, loyalitas merek

\begin{abstract}
Measuring brand equity becomes an important part in the organization, especially college. By measuring the brand equity, the college would be more understanding about its brand awareness, brand association, perceived quality, and brand loyalty. The Research problems were: (1) How were the students' perception about STIE Surakarta brand awareness?(2) How were the effects of brand association and perceived quality on brand loyalty. The samples of this research were 120 students of STIE Surakarta. The analysis used description and Structural Equation Modeling (SEM). The results showed that (1) the brand of STIE Surakarta occupied 3rd position in the minds of consumers; (2) Brand association had positive but insignificant effect on loyalty and perceived quality had positive and significant effect on brand loyalty.
\end{abstract}

Keywords: Brand equity, brand awareness, brand association, perceived quality, brand loyalty

\section{Pendahuluan}

Persaingan di Industri Pendidikan khususnya di daerah Surakarta sangat ketat. Ada berbagai perguruan tinggi baik swasta maupun negeri di Ex-Karisidenan Surakarta, misalnya Universitas Negeri Solo (UNS), Universitas Muhammadiyah Solo (UMS), Universitas Batik Surakarta (UNIBA), STIE Surakarta, STIE AAS, STIE Wijaya Mulya, STIMIK Sinar Nusantara, dan lain-lainnya. Namun perlu disadari, pesaing dari Sekolah Tinggi Ilmu Ekonomi (STIE) Surakarta bukan saja dari perguruan tinggi, melainkan berbagai lembaga pendidikan yang menyelenggarakan kursus-kursus tertentu, seperti SoloCom, Magistra Utama, dan lain-lainnya.
Membangun merek perguruan tinggi telah di bahas pada penelitian-penelitian sebelumnya (Casidy, 2013; Curtis, Abratt, \& Minor, 2009; Gray, Fam, \& Llanes, 2003; Pinar, Trapp, Girard, \& Boyt, 2011). Perguruan tinggi berlomba-lomba meningkatkan kesadaran dan citra mereknya. Berbagai cara dilakukan antara lain dengan menggunakan iklan, kegiatan-kegiatan, penyebaran brosur, presentasi ke SMASMA, menggunakan media sosial, dan masih banyak lagi. Berbagai literatur menjelaskan juga bagaimana perguruan tinggi mampu meningkatkan minat calon mahasiswa agar kuliah di perguruan tinggi tersebut. Beberapa strategi tersebut antara lain: strategi positioning (Niculescu, 2006), melakukan reformasi dan inovasi (Saginova \& Belyansky, 2008; Zhang, 
Zhao, \& Lei, 2012), mengembangkan tehnologi pembelajaran dan teknologi pendukungnya (Shurville, Browne, \& Whitaker, 2009), mengurangi kebingungan calon pendaftar (Drummond, 2004), meningkatkan kualitas pelayanan (Khan \& Matlay, 2009; Nicholls, Harris, Morgan, Clarke, \& Sims, 1995; Quintal, Wong, Sultan, \& Wong, 2012; Sharabi, 2013; Yeo, 2008), promosi yang menarik (Frolich \& Stensaker, 2010), memiliki jaringan internasional (Ottewill, Riddy, \& Fill, 2005) dan lainlainnya.

Pengelolaan ekuitas merek bukan sekedar dipakai untuk meningkatkan citra merek tersebut, namun yang perlu difokuskan adalah untuk membuat konsumen menjadi loyal terhadap merek tersebut. Ekuitas merek dibangun bukan hanya melalui fungsi pemasaran saja (Schreuer, 2000). Untuk membangun ekuitas merek, Schreuer (2000) percaya akan penggunaan tehnologi baru, saluran distribusi, hubungan, komunikasi dan pengalaman konsumen untuk meningkatkan nilainnya. Semakin tinggi ekuitas merek diharapkan mampu meningkatkan baik niat atau perilaku konsumen dalam membeli produk atau jasa tertentu.

Membuat konsumen sadar akan adanya merek merupakan langkah awal dalam pengelolaan merek. Kesadaran merek mengacu pada apakah konsumen tahu atau tidak tentang sebuah merek (Keller, 2003b). Merek yang dikenal akan membuat merek tersebut masuk dalam pertimbangan konsumen (Macdonald \& Sharp, 2000). Dalam konteks penelitian ini, mahasiswa sebagai konsumen sudah sadar dan mengenal merek STIE Surakarta dengan sangat baik. Oleh sebab itu, kesadaran merek dalam penelitian ini hanya berfokus pada level kesadaran merek, yaitu apakah merek STIE Surakarta menjadi top of mind, brand recall, atau brand recognition.
Asosiasi merek dan persepsi kualitas menjadi bagian penting dalam pengelolaan merek. Asosiasi merek akan membuat merek lebih cenderung dianggap memberikan berbagai pilihan dengan menghubungkan merek dengan tanda-tanda tertentu (Romaniuk, 2003) sedangkan persepsi kualitas terjadi karena adanya pembandingan antara apa yang diharapkan oleh konsumen dengan kinerja aktualnya (Parasuraman, Zeithaml, \& Berry, 1988). Baik asosiasi merek maupun persepsi kualitas memiliki pengaruh positif pada loyalitas (Das, 2014).

STIE Surakarta perlu mengelola ekuitas mereknya dengan hati-hati, baik kesadaran merek, asosiasi merek, dan persepsi kualitas. Sebab apabila terjadi kesalahan dalam pengelolaannya, maka bisa berakibat fatal. Kesalahan pengelolaan ekuitas merek akan membuat mahasiswa menjadi tidak puas. Mahasiswa yang tidak puas akan membuat berita yang negatif pada calon mahasiswa STIE Surakarta, dan hasil akhirnya adalah terjadinya penurunan penerimaan mahasiswa baru pada tahun yang akan datang. Selain hal tersebut, mahasiswa yang tidak puas tidak akan menjadi alumni yang baik.

Rumusan masalah dalam penelitian adalah (1) bagaimana persepsi mahasiswa tentang kesadaran merek STIE Surakarta; (2) bagaimana pengaruh asosiasi merek dan persepsi kualitas pada loyalitas merek STIE Surakarta.

\section{Ekuitas Merek}

Ekuitas merek merupakan salah satu konsep penting dalam praktek bisnis (Lassar, Mittal, \& Sharma, 1995). Ekuitas merek dapat diaplikasikan berbagai jenis bidang, antara lain untuk meningkatkan internet branding (Simmons, Thomas, \& Truong, 2010), olahraga profesional (Alexandris, Douka,

Tabel 1

\section{Definisi Ekuitas Merek}

\begin{tabular}{ll}
\hline \multicolumn{1}{c}{ Studi } & \multicolumn{1}{c}{ Penjelasan Konsep } \\
\hline Leuthesser (1988) & $\begin{array}{l}\text { Sekumpulan asosiasi dan perilaku dari konsumen, anggota saluran, dan korporasi yang } \\
\text { memungkinkan merek untuk mendapatkan volume atau margin yang lebih besar diban- } \\
\text { dingkan bila tanpa nama merek dan yang menjadikan merek menjadi kuat, berkelanjutan, } \\
\text { dan memiliki keunggulan bersaing dibandingkan dengan pesaing. }\end{array}$ \\
\hline Aaker (1991) & $\begin{array}{l}\text { Nilai yang diberikan konsumen berdasarkan asosiasinya pada merek, seperti yang dire- } \\
\text { fleksikan dalam dimensi kesadaran merek, asosiasi merek, persepsi kualitas, loyalitas me- } \\
\text { rek dan aset merek lainnya. }\end{array}$ \\
\hline Winter (1991) & $\begin{array}{l}\text { Ekuitas merek memberikan nilai tambah pada produk dengan asosiasi dan persepsi kon- } \\
\text { sumen pada nama merek. }\end{array}$ \\
\hline Keller (1993) & $\begin{array}{l}\text { Ekuitas merek merepresentasikan tingkat keakraban konsumen terhadap merek dan ke- } \\
\text { mampuan mengingat kembali merek berdasarkan asosiasi merek yang baik, kuat dan } \\
\text { unik. }\end{array}$ \\
\hline Vazquez, Del Rio, dan Iglesias & $\begin{array}{l}\text { Menggunakan konsep consumer-based brand equity, Vazquez et al. (2002) mendefinisi- } \\
\text { kannya sebagai utilitas total dari asosiasi konsumen untuk menggunakan dan mengkon- } \\
\text { (2002) }\end{array}$ \\
\hline
\end{tabular}


Papadopoulos, \& Kaltsatou, 2008; Gladden \& Milne, 1999; Gladden, Milne, \& Sutton, 1998), bidang pendidikan (Mourad, Ennew, \& Kortam, 2011), dan $B 2 B$ (Aaker, 2002; Kalafatis, Remizova, Riley, \& Singh, 2012; Keller \& Lehmann, 2006). Penelitianpenelitian tentang ekuitas merek menjelaskan bahwa memberikan nilai pada merek dipakai untuk mengembangkan strategi pemasaran yang efektif serta meningkatkan loyalitas konsumen (Gladden \& Funk, 2002 ; Keller, 1993; Low \& Lamb, 2000). Pentingnya ekuitas merek untuk konsumen karena ekuitas merek mampu meningkatkan pemahaman, proses informasi, kepercayaan diri saat mengambil keputusan, dan meningkatkan kepuasan untuk pemakai (Aaker, 1996b)

Ada berbagai sudut pandang untuk memahami ekuitas merek. Literatur pemasaran dan akuntansi berdebat tentang konsep ekuitas merek (Wood, 2000). Literatur pemasaran cenderung menilai merek dari persepsi konsumen, sedangkan literatur akuntansi cenderung menilai merek dari sisi goodwill dari perusahaan. Tabel 1 menunjukkan berbagai definisi tentang ekuitas merek.

Aaker (1996a) menjelaskan bahwa ekuitas merek dibagi ke dalam lima dimensi, antara lain kesadaran merek, asosiasi merek, persepsi kualitas, loyalitas merek dan kepemilikan aset lainnya. Gambar 1 menunjukkan tentang dimensi ekuitas merek.

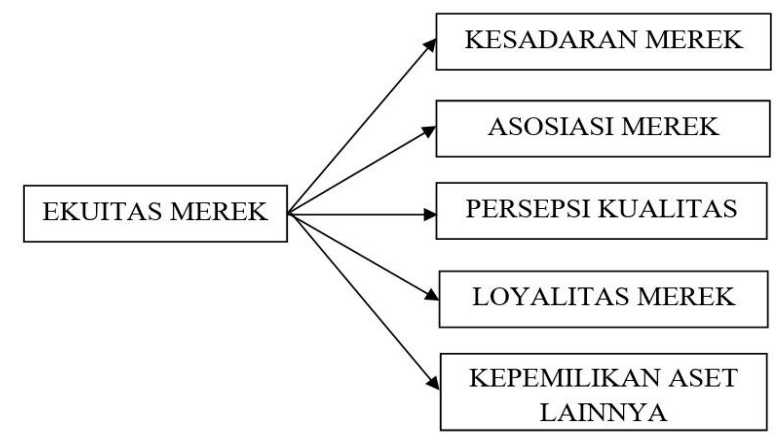

Gambar 1. Dimensi Ekuitas Merek

Sumber: Aaker (1991)

\section{Kesadaran Merek}

Kesadaran merek didefinisikan sebagai kemampuan konsumen untuk memanggil dan mengingat kembali merek sebagai refleksi dari kemampuan untuk mengidentifikasi merek pada kondisi yang berbeda dan menghubungkan nama merek, logo, simbol, dan dan sebagainya untuk asosiasi tertentu dalam memori (Keller, 1993). Aaker (1991) mendefinisikan kesadaran merek sebagai kemampuan calon pembeli (potential buyer) untuk mengenali (recognize) atau menyebutkan kembali (recall) suatu merek merupa- kan bagian dari suatu kategori produk. Aaker (1996b) kembali mendefiniskan kesadaran merek sebagai kekuatan merek pada benak konsumen.

Kesadaran merek berarti konsumen memiliki pengetahuan akan nama merek (Aaker, 1991; Keller, 1993). Kesadaran merek dapat mempengaruhi keputusan konsumen dalam membeli barang (Huang \& Sarigollu, 2012) khususnya untuk low involvement packged goods. Kesadaran merek juga memiliki peran penting dalam meningkatkan profitabilitas dan penjualan (Baldauf, Cravens, \& Binder, 2003) serta kinerja perusahaan (Kim \& Kim, 2005; Kim \& Kim, 2004).

Dimensi atau indikator dari kesadaran merek adalah top of mind, brand recall, brand recognition, dan unware brand (Aaker, 1996b). Top of mind adalah nama merek yang ada di puncak pikiran manusia, ketika seseorang bertanya sebuah merek dalam suatu kategori maka merek tersebut muncul pertama kali. Brand Recall adalah merek yang disebutkan oleh konsumen setelah merek yang masuk dalam kategori top of mind, tanpa bantuan merek tersebut dapat diingat. Brand recognition adalah merek yang disebutkan namun perlu bantuan. Unware brand adalah merek yang tidak diingat konsumen walaupun sudah diberi bantuan untuk mengingatnya.

\section{Asosiasi Merek}

Beberapa ahli mendefinisikan asosiasi merek. Keller (1993) mendefinisikan asosiasi merek sebagai simpul informasi yang terkait dengan simpul merek dalam memori dan memiliki arti bagi pelanggan. Asosiasi merek juga terkait dengan informasi tentang apa yang ada dalam benak pelanggan tentang merek, baik positif atau negatif, terhubung ke simpul memori otak (Emari, Jafari, \& Mogaddam, 2012). Asosiasi merek terdiri dari keseluruhan merek yang berhubungan dengan pikiran, perasaan, persepsi, citra, pengalaman, kepercayaan, sikap (Kotler, 2006) dan segala sesuatu yang berhubungan dengan memori tentang merek (Chieng \& Lee, 2011). Phan dan Ghantous (2013) membedakan asosiasi merek yang berhubungan dengan citra perusahaan jasa ke dalam dua jenis, antara lain asosiasi berbasis korporat dan asosiasi berbasis pengalaman.

Keller (1993) membagi asosiasi merek ke dalam tiga jenis. Pertama, atribut. Atribut didefinisikan sebagai ciri-ciri atau karakteristik dari produk. Atribut dikategorikan ke dalam dua jenis, yaitu atribut yang berhubungan dengan produk (berhubungan dengan komposisi atau kebutuhan fisik produk atau jasa) dan atribut yang berhubungan dengan bukan produk (faktor ekstenal yang berhubungan dengan produk, seper- 
ti harga, kemasan, dan lain-lainnya). Kedua adalah manfaat. Manfaat adalah dengan persepsi konsumen yang dihubungkan dengan nilai produk dan hasil yang akan dicapai. Manfaat dikategorikan ke dalam tiga kategori, yaitu manfaat fungsional, manfaat fungsional, dan manfaat simbolik (Keller, 2003a). Ketiga adalah sikap merek. Sikap merek didefinisikan sebagai evaluasi keseluruhan tentang merek.

Beberapa peneliti menjelaskan tentang dimensi asosiasi merek. Del Rio, Vázquez-Casielles, dan Iglesias (2001) menjelaskan dimensi garansi, identifikasi personal, identifikasi sosial, dan status. Keller (1993) menjelaskan dimensi asosiasi merek ke dalam tiga kategori: atribut, fungsi, dan sikap. Namun dalam penelitian ini peneliti mengusulkan tiga dimensi untuk mengukur asosiasi merek dari perguruan tinggi, antara lain kekuatan, keberbedaan, dan keunikan. Dimensi kekuatan diartikan sebagai persepsi konsumen yang menyatakan kemampuan sebuah merek dalam memenangkan pasar. Dimensi keberbedaan berarti persepsi konsumen tentang adanya perbedaan spesifik antara satu merek dengan merek lainnya. Dimensi Keunikan adalah persepsi konsumen yang menyatakan bahwa merek memiliki keunikan dibandingkan dengan merek lainnya.

\section{Persepsi Kualitas}

Chieng dan Lee (2011) menjelaskan bahwa persepsi kualitas cenderung menjadi dimensi dari ekuitas merek dibandingkan dengan asosiasi merek. Persepsi kualitas didefinisikan sebagai penilaian pelanggan tentang keunggulan keseluruhan produk atau superioritas dari kualitas objektif (Zeithaml, 1988). Persepsi kualitas adalah sikap yang dihasilkan dari perbandingan harapan konsumen dengan kinerja aktual (Parasuraman et al., 1988).

Zeithaml (1988) menjelaskan bahwa persepsi kualitas dibagi menjadi dua kelompok, yaitu intrinsik dan ekstrinsik. Intrinsik menyangkut aspek fisik dari produk (warna, rasa, bentuk, dan lain-lainnya), sedangkan ekstrinsik berhubungan dengan aspek bukan fisik dari produk (nama merek, harga, informasi tentang produk). Brady, Cronin, dan Brand (2002) mempertimbangkan dimensi dari persepsi kualitas terdiri dari kualitas tehnis dan kualitas fungsional. Dalam penelitian ini, persepsi kualitas mengacu pada SERVQUAL dari Parasuraman et al. (1988) yaitu aspek fisik, empati, jaminan, responsif, dan kehandalan.

Persepsi kualitas khususnya kualitas pelayanan menjadi salah satu bagian penting dalam mengembangkan perguruan tinggi. Beberapa peneliti memperlihatkan peran kualitas pelayanan dalam perguruan tinggi (Khan \& Matlay, 2009; Nicholls et al., 1995; Quintal et al., 2012; Sharabi, 2013; Yeo, 2008). Persepsi kualitas pelayanan sangat penting karena mampu meningkatkan loyalitas konsumen (Giovanis, Zondiros, \& Tomaras, 2014; Gurbuz, 2008; Kranias \& Bourlessa, 2013; Segoro, 2013; Shi, Prentice, \& $\mathrm{He}, 2014)$

\section{Loyalitas Merek}

Beberapa ahli melihat loyalitas merek dalam berbagai perspektif. Ada yang menjelaskan loyalitas merek sebagai keterikatan konsumen pada merek (Aaker, 1991), pembelian ulang (Keller \& Lehmann, 2006), komitmen membeli kembali merek (Oliver, 1999), harga premium (Aaker, 1996b; Chaudhuri \& Holbrook, 2001). Dick dan Basu (1994) melihat loyalitas ke dalam dua bagian, yaitu relative attitute dan repeat patronage. Odin, Odin, dan Valette-Florence (2001) melihat loyalitas melalui dua pendekatan yaitu stokhastik (loyalitas sebagai tindakan) dan deterministik (loyalitas sebagai sikap loyal seseorang pada merek tertentu). Mellens, Dekimpe, dan Steenkamp (1996) dan Rundle-Thiele dan Mackay (2001) menganalisis dimensi loyalitas dibagi ke dalam dua dimensi, yaitu loyalitas sikap (preferensi, komitmen, dan niat untuk membeli ulang) dan loyalitas tindakan (tindakan pembelian ulang pada periode waktu tertentu). Di dalam penelitian ini, kami mengusulkan seseorang yang loyal pada universitas, maka akan dilihat dari beberapa dimensi, yaitu tidak punya keinginan untuk pindah, rekomendasi, dan menjadi alumni.

\section{Pengaruh Asosiasi Merek pada Loyalitas Merek}

Asosiasi merek di dalam memori konsumen merupakan komponen dasar dari Customer-Based Brand Equity (Christodoulides \& De Chernatony, 2010; Keller, 2003a). Keller (1993) membuat konsep tentang pengetahuan merek sebagai asosiasi di dalam benak konsumen yang dibedakan oleh rasa suka, kekuatan, dan keunikan. Pengetahuan dan asosiasi tersebut akan dapat mendorong konsumen mengevaluasi atau memberi respon dengan tindakan (Koll \& Von Wallpach, 2014), misalnya komitmen, kepercayaan, kepercayaan, niat membeli, pembelian, rekomendasi (Bapat, 2013; Broniarchzyk \& Alba, 1994; Janiszewski \& Van Osselaer, 2000; Lane, 2003), bahkan loyalitas pada merek tertentu (Alexandris et al., 2008; Bapat, 2013; Phan \& Ghantous, 2013).

Fokus penelitian ini adalah industri pendidikan khususnya perguruan tinggi. Kami berpendapat bahwa ada tiga indikator dari perguruan tinggi, yaitu 
kekuatan, keberbedaan, dan keunikan (Till, Baack, \& Waterman, 2001) akan mampu meningkatkan secara signifikan loyalitas mahasiswa terhadap STIE Surakarta. Berdasarkan kajian hasil empiris tersebut, maka dapat dibangun hipotesis yakni:

$H_{l}$ : Asosiasi merek memiliki pengaruh positif dan signifikan pada loyalitas merek.

\section{Pengaruh Persepsi Kualitas Pada Loyalitas Merek}

Parasuraman et al. (1988) berpendapat bahwa persepsi konsumen merupakan yang dihasilkan dari perbandingan harapan konsumen dengan kinerja aktual. Apabila kinerja aktual dari merek lebih dari yang diharapkan, maka akan muncul sikap positif konsumen pada merek tersebut. Sikap positif pada sebuah merek dapat memprediksi perilaku seseorang (Cherian \& Jacob, 2012), baik niat membeli ulang ataupun tindakan pembelian ulang (Cho, Rha, \& Burt, 2015).

Penelitian-penelitan terdahulu menunjukkan bahwa persepsi kualitas mampu meningkatkan loyalitas merek (Giovanis et al., 2014; Gurbuz, 2008; Kranias \& Bourlessa, 2013; Segoro, 2013; Shi et al., 2014). Penelitian-penelitian tersebut bukan hanya pada satu industri saja melainkan beraneka industri, seperti retail (Gurbuz, 2008), bank (Kranias \& Bourlessa, 2013), kasino (Shi et al., 2014), selular (Giovanis et al., 2014; Segoro, 2013). Penelitian ini berfokus pada industri pendidikan, khususnya perguruan tinggi. Berdasarkan kajian hasil empiris tersebut, maka dapat dibangun hipotesis yakni:

$\mathrm{H}_{2}$ : Persepsi kualitas memiliki pengaruh positif dan signifikan pada loyalitas merek.

\section{Model Penelitian Empiris}

Gambar 2 merupakan model penelitian empiris;

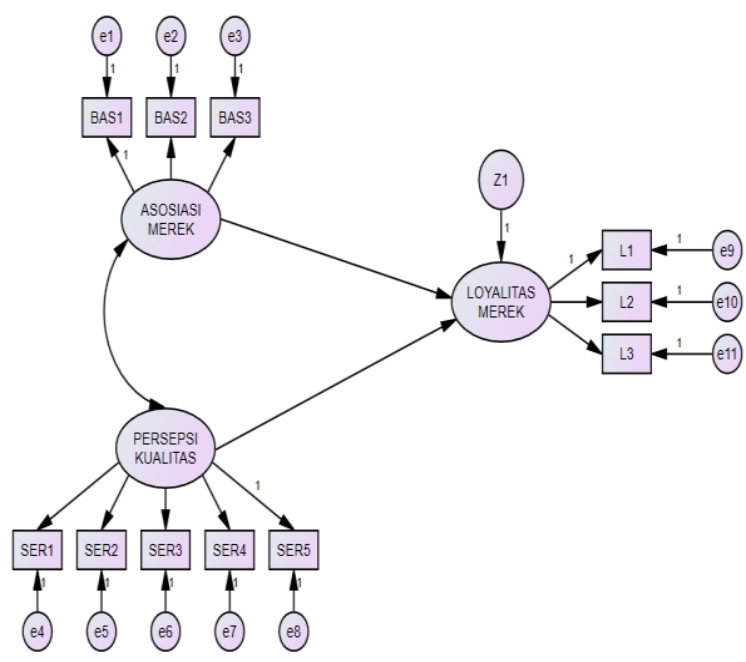

Gambar 2. Model Penelitian Empiris

\section{Metode Penelitian}

\section{Sampel, Teknik Pengambilan Sampel, dan Analisis}

Kuesioner disebar kepada 200 mahasiswa STIE Surakarta, namun hanya 120 responden saja yang datanya bisa dilanjutkan pada tahap berikutnya. Teknik pengambilan sampel adalah dengan menggunakan simple random sampling.

Analisis penelitian ini menggunakan dua metode, yaitu analisis deskriptif dan Structural Equation Modeling (SEM). Analisis deskriptif adalah analisis yang dilakukan dengan cara mendeskripsikan data setelah melakukan tabulasi pada masing-masing indikator penelitian. Structural Equation Modeling merupakan analisis multivariat yang dipakai untuk menguji sebab akibat. Untuk mengolah data, penelitian ini menggunakan alat bantu yaitu Amos versi 20.

\section{Operasionalisasi Variabel}

Berikut operasionalisasi variabel dapat dilihat pada Tabel 2.

Tabel 2

Variabel Operasional

\begin{tabular}{|c|c|c|}
\hline Variabel \& Definisi & Indikator & Sumber \\
\hline $\begin{array}{l}\text { Asosiasi Merek adalah } \\
\text { asosiasi merek sebagai } \\
\text { simpul informasi yang } \\
\text { terkait dengan simpul } \\
\text { merek dalam memori } \\
\text { dan memiliki arti merek } \\
\text { bagi konsumen. }\end{array}$ & $\begin{array}{l}\text { - Kekuatan } \\
\text { - Keberbedaan } \\
\text { - Keunikan }\end{array}$ & Till et al. (2001) \\
\hline $\begin{array}{l}\text { Persepsi Kualitas adalah } \\
\text { sebagai penilaian pelang } \\
\text { gan tentang keunggulan } \\
\text { keseluruhan produk atau } \\
\text { superioritas dari kualitas } \\
\text { objektif. }\end{array}$ & $\begin{array}{l}\text { - Aspek fisik } \\
\text { - Empati } \\
\text { - Jaminan } \\
\text { - Responsif } \\
\text { - Kehandalan. }\end{array}$ & $\begin{array}{ll}\text { Parasuraman } & \text { et } \\
\text { al. (1988) } & \end{array}$ \\
\hline $\begin{array}{l}\text { Loyalitas Merek adalah } \\
\text { keinginan untuk tidak } \\
\text { berpindah dari satu } \\
\text { merek. }\end{array}$ & $\begin{array}{l}\text { - Tidak pindah } \\
\text { - Alumni } \\
\text { - Rekomendasi }\end{array}$ & $\begin{array}{l}\text { Brown dan } \\
\text { Mazzarol (2009) }\end{array}$ \\
\hline
\end{tabular}

\section{Hasil Penelitian dan Pembahasan}

Untuk menganalisis kesadaran merek mahasiswa STIE Surakarta, peneliti menggunakan pertanyaan terbuka. Peneliti meminta responden untuk menyebutkan tujuh merek perguruan tinggi yang dikenal mahasiswa di Eks-Karesidenen Surakarta. Jawaban pertama dari pertanyaan itu akan diberi nilai 7, jawaban ke-2 diberi nilai 6, sampai jawaban ke-7 akan diberi nilai 1 . Lalu hasilnya akan dibuat rata-rata. Hasil outputnya seperti pada Tabel 3 . 
Dalam kesadaran merek, ada empat tingkatan yaitu top of mind, brand recall, brand recognition dan unware brand. Pada penelitian ini hanya akan melihat kesadaran merek dari top of mind dan brand recall. Top of mind dilihat dari rata-rata merek yang pertama kali disebutkan oleh mahasiswa STIE Surakarta, sedangkan brand recall merupakan merek yang disebutkan setelah top of mind. Dari Tabel 3, dapat disimpulkan bahwa merek STIE Surakarta tidak menempati top of mind pada benak mahasiswa. Di dalam benak mahasiswa, Merek STIE Surakarta menempati posisi ke-3.

Tabel 3

Indeks Persepsi Mahasiswa tentang Perguruan Tinggi

\begin{tabular}{lclc}
\hline \multicolumn{1}{c}{$\begin{array}{c}\text { Perguruan } \\
\text { Tinggi }\end{array}$} & $\begin{array}{c}\text { Nilai } \\
\text { Indeks }\end{array}$ & $\begin{array}{c}\text { Perguruan } \\
\text { Tinggi }\end{array}$ & $\begin{array}{c}\text { Nilai } \\
\text { Indeks }\end{array}$ \\
\hline UNS & 5,864 & IAIN & 0,309 \\
UMS & 5,123 & UNIVET & 0,272 \\
STIES & 4,247 & USB & 0,235 \\
UNIBA & 3,074 & STIMIK DUTA & 0,111 \\
& & BANGSA & \\
UNISRI & 2,864 & STIE AAS & 0,099 \\
AUB & 1,58 & ATMI & 0,099 \\
UNSA & 1,284 & UNIV. SAHID & 0,086 \\
STIMIK SINUS & 0,753 & UNIVERSITAS & 0,049 \\
& & TERBUKA & \\
ISI & 0,63 & STIKES & 0,012 \\
& & AISIYAH & \\
UTP & 0,494 & STIE ATMA & 0,012 \\
& & BAKTI & \\
ATW & 0,346 & & \\
& & &
\end{tabular}

Tabel 4 menunjukkan validitas dan reliabilitas penelitian ini. Reliabilitas penelitian ini dilihat dari Crobach Alpha dan construct reliability, sedangkan validitas penelitian ini dilihat dari convergent validity dan AVE.

- Cronbach Alpha. Nilai cut off dari cronbach alpha adalah 0,6. Variabel-variabel yang di teliti pada penelitian ini adalah reliabel sebab nilainya di atas nilai cut-off (Asosiasi Merek: 0,869; Persepsi Kualitas: 0,937; dan Loyalitas Merek: 0,85).

- Contruct Reliablitity. Nilai cut off dari construct reliability adalah 0,7 (Ghozali, 2013). Variabel-variabel yang diteliti pada penelitian ini adalah reliabel sebab nilainya di atas nilai cut-off (Asosiasi Merek: 0,867; Persepsi Kualitas: 0,949; dan Loyalitas Merek: 0,81).

- AVE. Nilai cut off dari $A V E$ adalah 0,5 (Ghozali, 2013). Variabel-variabel yang diteliti tersebut memiliki validitas sebab semua nilainya di atas nilai cut-off (Asosiasi Merek: 0,827; Persepsi Kualitas: 0,889; dan Loyalitas Merek: 0,767).
- Convergent Validity. Nilai cut off dari convergent validity adalah 0,7 (Ghozali, 2013). Semua indikator tiap tiap variabel adalah valid sebab nilainya di atas nilai cut-off.

Tabel 4

Validitas dan Reliabilitas

\begin{tabular}{lcccc}
\hline & Cronbach & Construct & Convergent & Ave \\
& Alpha & Reliability & Validity & \\
\hline ASOSIASI MEREK & 0,869 & 0,867 & & 0,827 \\
BAS1 (Kekuatan) & & & 0,804 & \\
BAS2 (Keberbedaan) & & & 0,856 & \\
BAS3 (Keunikan) & & & 0,834 & \\
PERSEPSI KUALITAS & 0,937 & 0,949 & & 0,889 \\
SER1 (Fasilitas Fisik) & & & 0,882 & \\
SER2 (Kecepatan) & & & 0,928 & \\
SER3 (Empati) & & & 0,896 & \\
SER4 (Jaminan) & & & 0,835 & \\
SER5 (Kehandalan) & & & 0,795 & \\
LOYALITAS MEREK & 0,85 & 0,81 & & 0,767 \\
L1 (Tidak Pindah) & & & 0,772 & \\
L2 (Menjadi Alumni) & & & 0,753 & \\
L3 (rekomendasi) & & & 0,91 & \\
\hline
\end{tabular}

Indikasi model fit apabila data yang dimiliki fit dengan model yang dibangun. Model fit pada penelitian ini dilihat dari nilai NFI, TLI dan CFI. Cut-off dari ketiga nilai tersebut adalah 0,9 (Ghozali, 2013). Dari Gambar 3 dapat diketahui bahwa nilai $N F I$ $(0,916), T L I(0,930)$, dan $C F I(9,48)$ di atas nilai cutoff, sehingga dapat dikatakan bahwa model yang di bangun sudah fit dengan data.

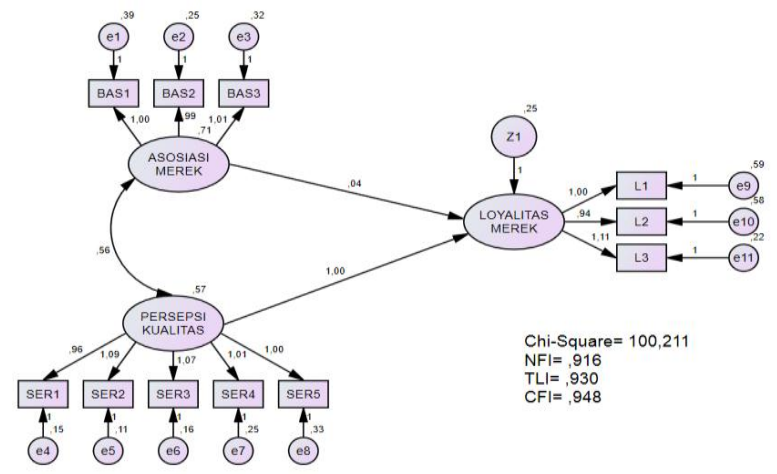

Gambar 3. Hasil Analisis Model Struktural

Tabel 5

Hasil Pengujian Hipotesis Penelitian

\begin{tabular}{rccc}
\hline Hipotesis & Koefisien & $p$ & Keterangan \\
\hline Loyalitas $\leftarrow$ Asosiasi Merek & 0,040 & 0,847 & Hipotesis \\
& & & Ditolak \\
Loyalitas Merek $\leftarrow$ Persepsi & 1,000 & $* * *$ & Hipotesis \\
Kualitas & & & Diterima \\
\hline
\end{tabular}

Berdasarkan Tabel 5, terdapat dua hipotesis yang telah diuji dan hasilnya menunjukkan satu hi- 
potesis diterima dan satu hipotesis ditolak. Hipotesis yang ditolak adalah asosiasi merek memiliki pengaruh positif dan signifikan pada loyalitas merek (koefisien $=0,040 ; p=0,847)$. Hasil penelitian tersebut menjelaskan bahwa pengaruh antara asosiasi merek pada loyalitas merek tidak signifikan. Hipotesa yang diterima adalah persepsi kualitas memiliki pengaruh positif dan signifikan pada loyalitas merek (koefisien $=1,000 ; p<0,05$ ).

\section{Pembahasan}

Sejak muncul pada tahun 1980an, konsep ekuitas merek menjadi bagian penting baik bagi akademisi ataupun praktisi (Cobb-Walgren, Ruble, \& Donthu, 1995). Ekuitas merek sendiri didefinisikan sebagai nilai yang diberikan konsumen berdasarkan asosiasinya pada merek, seperti yang direfleksikan dalam dimensi kesadaran merek, asosiasi merek, persepsi kualitas, loyalitas merek dan aset merek lainnya.

Penelitian ini menemukan adanya suatu keanehan tentang kesadaran merek mahasiswa STIE Surakarta. Hasil penelitian ini menemukan bahwa peringkat kesadaran tertinggi (top of mind) mahasiswa STIE Surakarta bukan pada merek STIE Surakarta. Merek STIE Surakarta hanya menempati posisi ke-3 atau sebagai brand recall.

Hasil uji hipotesa menunjukkan bahwa asosiasi merek memiliki pengaruh positif tetapi tidak efisien pada loyalitas merek. Asosiasi merek yang meliputi kekuatan, keberbedaan, dan keunikan tidak mampu secara signifikan membuat mahasiswa loyal pada STIE Surakarta. Artinya membangun asosiasi tertentu bagi mahasiswa bukan sesuatu yang vital bagi loyalitas mahasiswa. Membangun asosiasi atau citra lebih cocok dan berguna pada promosi kampus, yaitu berfungsi untuk menjaring calon mahasiswa baru. Hasil penelitian ini bertentangan dengan penelitian sebelumnya. Penelitian sebelumnya menunjukkan bahwa asosiasi merek memiliki pengaruh positif dan signifikan pada loyalitas merek (Alexandris et al., 2008; Phan \& Ghantous, 2013).

Persepsi kualitas memiliki pengaruh positif dan signifikan pada loyalitas merek. Persepsi kualitas yang meliputi aspek fisik, empati, jaminan, responsif, dan kehandalan mampu secara signifikan meningkatkan loyalitas pelanggan. Hasil penelitian ini sama dengan penelitian sebelumnya. Hasil penelitian sebelumnya menunjukkan bahwa persepsi kualitas memiliki pengaruh positif dan signifikan pada loyalitas merek (Giovanis et al., 2014; Gurbuz, 2008; Kranias \& Bourlessa, 2013; Segoro, 2013; Shi et al., 2014).

\section{Simpulan dan Implikasi}

Hasil penelitian ini menjelaskan bahwa posisi STIE Surakarta di benak mahasiswa adalah brand recall. Ada beberapa indikasi mengapa STIE Surakarta tidak menjadi top of mind di dalam benak konsumen. Pertama, ada kemungkinan mahasiswa STIE Surakarta memandang UNS dan UMS sebagai kampus besar dan lebih unggul dibanding STIE Surakarta. Oleh sebab itu, di dalam benak mahasiswa, UNS dan UMS menempati posisi paling tinggi. Kedua, ada kemungkinan STIE Surakarta memang bukan pilihan utama dari mahasiswa. Harus ada upaya yang dilakukan oleh agar posisi merek STIE Surakarta menempati top of mind di benak mahasiswa misalnya saja: (1) membangun pengetahuan konsumen dengan cara memberikan edukasi kepada mahasiswa tentang visi, filosofi, budaya, dan kelebihan STIE Surakarta dibandingkan dengan perguruan tinggi lainnya, (2) membangun hubungan emosional antara karyawan, dosen, alumni, dan mahasiswa. Semakin erat hubungan beberapa pihak tersebut, maka diharapkan posisi STIE Surakarta di benak konsumen menjadi top of mind; dan (3) membuat seluruh mahasiswa aktif dalam berbagai kegiatan di kampus. Ketiga strategi tersebut akan menyentuh sisi kognitif, afektif, dan perilaku mahasiswa.

Asosiasi merek memiliki pengaruh tidak signifikan pada loyalitas merek. Hasil penelitian ini mengindikasikan bahwa mahasiswa STIE Surakarta tidak terlalu MEM asosiasi-asosiasi apa saja yang dibangun oleh STIE Surakarta. Tujuan pembangunan asosiasi sebenarnya adalah untuk menarik calon mahasiswa STIE Surakarta, bukan untuk meningkatkan loyalitas mahasiswa STIE Surakarta.

Peningkatan kegiatan yang unik dan berbeda serta membangun daya saing STIE Surakarta, dibandingkan kampus lain akan mampu meningkatkan loyalitas mahasiswa. Kualitas yang dipersepsikan memiliki pengaruh positif dan signifikan pada loyalitas merek. Mahasiswa telah merasakan pelayanan baik dari dosen ataupun karyawan STIE Surakarta. Pelayanan tersebut membuat mahasiswa tidak akan berpindah ke kampus lain, menjadi alumni, bahkan memberikan informasi kepada pihak lain.

Ada beberapa hal yang harus diperhatikan tentang meningkatkan persepsi kualitas mahasiswa, antara lain: (1) adanya perbaikan pada fasilitas-fasilitas seperti perpustakaan, kantin, ruang kelas, dan aula. (2) memberikan berbagai pelatihan tentang pelayanan prima pada karyawan, sehingga karyawan mampu memberikan pelayanan terbaik pada mahasiswa.

Temuan penelitian ini memberikan masukan bagi penelitian di bidang manajemen merek, khususnya 
penelitian tentang ekuitas merek. Studi yang kami lakukan berfokus pada ekuitas merek perguruan tinggi swasta, khususnya STIE Surakarta. Konsumen perguruan tinggi adalah mahasiswa yang studi aktif pada perguruan tinggi tersebut. Dari sisi konsumen, persepsi kualitas (khususnya kualitas pelayanan) lebih memberikan kontribusi yang signifikan bagi loyalitas merek dibandingkan dengan hanya membangun asosiasi-asosiasi tertentu.

Penelitian ini memiliki beberapa keterbatasan, antara lain: (1) dimungkinkan responden dalam mengisi kuesioner kurang objektif karena statusnya yang masih menjadi mahasiswa STIE Surakarta; (2) model penelitian masih cukup sederhana.

Untuk penelitian yang akan datang, kami menyarankan (1) Dengan satu model yang sama, kita membandingkan apakah hasilnya sama apabila kita meneliti 2 atau lebih perguruan tinggi (membandingkan antara kampus swasta dan negeri); (2) gunakan variabel moderasi, seperti demografi responden. (3) Sampel penelitian adalah alumni perguruan tinggi; (4) membandingkan antara ekuitas merek berbasis persepsi konsumen dengan berbasis akuntansi.

\section{Daftar Referensi}

Aaker, D. (1991). Managing brand equity: Capitalizing on the value of a brand name. New York: Free Press. - (1996a). Building strong brands. New York: The Free Press. (1996b). Measuring brand equity across product and markets. California Management Review, 38(3), 102-120. -- (2002). Building strong brand. London: Simon \& Schuster.

Alexandris, K., Douka, S., Papadopoulos, P., \& Kaltsatou, A. (2008). Testing the role of service quality on the development of brand association and brand loyalty. Managing Service Quality: An International Journal, 18(3), 239-254.

Baldauf, A., Cravens, K. S., \& Binder, G. (2003). Performance consequences of brand equity management: Evidence from organizations in the value chain. Journal of Product \& Brand Management, 12(4), 220-236.

Bapat, D. (2013). The Relationship of brand association and loyalty: An empirical study for retail banking in India. Global Conference on Business and Finance Proceedings, 8(1), 417-423.

Brady, M. K., Cronin, J. J., \& Brand, R. R. (2002). Performance-only measurement of service quali- ty: A replication and extension. Journal of Business Research, 55, 27-31.

Broniarchzyk, S. M., \& Alba, J. W. (1994). The role of consumers' intuitions in inference making. Journal of Consumer Research, 21(3), 393-407.

Brown, M. R., \& Mazzarol, T. W. (2009). The Important of institutional image to student satisfaction and loyalty within higher education. Higher Education, 58, 81-95.

Casidy, R. (2013). The role of brand orientation in the higher education sector: A student-perceived paradigma. Asia Pasific Journal of Marketing and Logistics, 25 (5), 803-820.

Chaudhuri, A., \& Holbrook, M. B. (2001). The chain of effects from brand trust and brand affect to brand performance: The role of brand loyalty. Journal of Marketing, 65(2), 81-94.

Cherian, J., \& Jacob, J. (2012). Green marketing: A study of consumers' attitude toward environment frienly product. Asian Social Science, 8(2), 117-126.

Chieng, F. Y. L., \& Lee, G. C. (2011). Customerbased brand equity: A literature review. Journal of Arts Science \& Commerce, 2(1), 33-42.

Cho, Y. S., Rha, H. S., \& Burt, S. (2015). The Impact of customer awareness of manufacturer name disclosure on retail brand attitudes and loyalty in Korea. Journal of Retailing and Consumer Service, 22, 128-137.

Christodoulides, G. \& De Chernatony, L. (2010). Consumer-based brand equity conseptualization and measurement. International Journal of Market Research, 52(1), 43-66.

Cobb-Walgren, C. J., Ruble, C. A., \& Donthu, N. (1995). Brand equity, brand preference, and purchase intent. Journal of Advertising, 24(3), 2540.

Curtis, T., Abratt, R., \& Minor, W. (2009). Corporate brand management in higher education: The case of erau. 18(6), 404-413.

Das, G. (2014). Lingkages of retailer awareness, retailer association, retailer perceived quality, and retailer loyalty with purchase intention: A study of indian food retail brands. Journal of Retailing and Consumer Services, 21, 284-292.

Del Rio, A. B., Va'zquez-Casielles, R., \& Iglesias, V. (2001). The effect of brand association on consumer response. Journal of Consumer Marketing, 18(5), 410-425.

Dick, A. S., \& Basu, K. (1994). Customer loyalty: Toward an integrated conceptual framework. Journal of the Academy of Marketing Science, 22(2), 99-113. 
Drummond, G. (2004). Consumer confusion: Reduction strategies in higher education. International Journal of Educational Management, 18(5), 317 -323 .

Emari, H., Jafari, A., \& Mogaddam, M. (2012). The mediatory impact of brand loyalty and brand image on brand equity. African Journal of Business Management, 6 (17), 5692-5701.

Frolich, N. \& Stensaker, B. (2010). Student recruitment strategies in higher education: Promoting excellence and diversity? International Journal of Educational Management, 24(4), 359-370.

Ghozali, I. (2013). Model persamaan struktural: Konsep dan aplikasi dengan program AMOS 21. Semarang: Universitas Diponegoro.

Giovanis, A. N., Zondiros, D., \& Tomaras, P. (2014). The antecendents of customer loyalty for broadband services: The role of service quality, emotional satisfaction and corporate image. Procedia-Social and Behavioral Sciences, 148, 236 $-244$.

Gladden, J. \& Funk, D. (2002). Developing an understanding of brand association in team sport: Empirical evidence from consumers of professional sport. Journal of Sport Management, 16(1), 54-81.

Gladden, J., \& Milne, G. (1999). Examining the importance understanding of brand equity in professional sports. Sport Marketing Quarterly, $8(1), 21-29$.

Gladden, J., Milne, G., \& Sutton, W. (1998). A conceptual framework for evaluating brand equity in division 1 college athletics. Journal of Sport Management, 12, 1-19.

Gray, B. J., Fam, K. S., \& Llanes, V. A. (2003). Branding university in asian markets. Journal of Product \& Brand Management, 12(2), 108-120.

Gurbuz, E. (2008). Retail sore branding in Turkey: Its effect on perceived quality, satisfaction, and loyalty. EuroMed Journal of Business, 3(3), 286304.

Huang, R., \& Sarigollu, E. (2012). How brand awareness related to market outcome, brand equity, and the marketing mix. Journal of Business Research, 65, 92-99.

Janiszewski, C., \& Van Osselaer, S. M. J. (2000). A connectionist model of brand-quality associations. Journal of Marketing Research, 37(August), 331-350.

Kalafatis, S. P., Remizova, N., Riley, D., \& Singh, J. (2012). The differential impact of brand equity on b2b co-branding. Journal of Business \& Industrial Marketing, 27(8), 623-634.
Keller, K. L. (1993). Conceptualizing, measuring, and managing customer based brand equity. Journal of Marketing, 57(1), 1-22.

(2003a). Brand systesis: The multidimensional of brand knowledge. Journal of Consumer Research, 29(March), 595-600.

----- (2003b). Strategic brand management: Building, measuring, and managing brand equity. Upper Saddle River, NJ.: Pearson.

Keller, K. L., \& Lehmann, D. R. (2006). Brand and branding: Research finding and future priority. Marketing science, 25(6), 740-759.

Khan, H., \& Matlay, H. (2009). Implementing service excellence in higher education. Education + Training, 51(8/9), 769-780.

Kim, H. B. \& Kim, W. G. (2005). The relationship between brand equity and firms' performance in luxury hotels and chain restaurants. Tourism Management, 26, 549-560.

Kim, W. G., \& Kim, H. B. (2004). Measuring customer-based restaurant brand equity. Cornell Hotel and Restaurant Administration Quarterly, 45(2), 115-131.

Koll, O., \& Von Wallpach, S. (2014). Intended brand associations: Do they really drive consumer response. Journal of Business Research, 67, 1501-1507.

Kotler, P. (2006). Marketing management. Upper Saddle River, New Jersey: Pearson Education, Inc.

Kranias, A. \& Bourlessa, M. (2013). Investigating the relationship between service quality and loyalty in Greek banking sector. Procedia Economics and Finance, 5, 453-458.

Lane, V. R. (2003). The Impact of ad repetition and ad content on consumer perceptions of incongruent extensions. Journal of Marketing, 64(2), 80-91.

Lassar, W., Mittal, B., \& Sharma, A. (1995). Measuring customer-based brand equity. Journal of Consumer Marketing, 12(4), 11-19.

Leuthesser, L. (1988). Defining, measuring, and managing brand equity. Paper presented at the Conference Summary, Cambridge, MA.

Low, G., \& Lamb, C. (2000). The measurement and dimensionality of brand associations. Journal of Product and Brand Management, 9(6), 350370.

Macdonald, E. K. \& Sharp, B. M. (2000). Brand awareness effects on consumer decision making for common, repeat purchase product: A replication. Journal of Business Research, 48, 5 -15 . 
Mellens, M., Dekimpe, M. G., \& Steenkamp, J. B. E. M. (1996). A review of brand loyalty measures in marketing. Tijdschrift voor Economie en Management, 41, 507-533.

Mourad, M., Ennew, C. T., \& Kortam, W. (2011). Brand equity in higher education. Marketing Intelligence \& Planning, 29(4), 403-420.

Nicholls, J., Harris, J., Morgan, E., Clarke, K., \& Sims, D. (1995). Marketing higher education: The mba experience. International Journal of Educational Management, 9(2), 31-38.

Niculescu, M. (2006). Strategic positioning in romanian higher education. Journal of Organizational Change Management, 19(6), 725-737.

Odin, Y., Odin, N., \& Valette-Florence, P. (2001). Conceptual and operational aspects of brand loyalty: An empirical investigation. Journal of Business Research, 53, 74-84.

Oliver, R. L. (1999). Whence consumer loyalty? Journal of Marketing, 63(special issue), 33-34.

Ottewill, R., Riddy, P., \& Fill, K. (2005). International networks in higher education: Realising their potential? On The Horison, 13(3), 138-147.

Parasuraman, A., Zeithaml, V. A., \& Berry, L. L. (1988). SERVQUAL: a multiple-item scale for measuring customer perceptions of service quality. Journal of Retailing, 64(1), 12-40.

Phan, K. N., \& Ghantous, N. (2013). Managing brand associations to drive customers' trust and loyalty in vietnamese banking. International Journal of Bank Marketing, 31(6), 456-480.

Pinar, M., Trapp, P., Girard, T., \& Boyt, T. E. (2011). Utilizing the brand ecosystem framework in designing brand strategy for higher education. International Journal of Educational Management, 25(7), 724-739.

Quintal, V. A., Wong, D. H., Sultan, P., \& Wong, Y. Y. (2012). Service in a higher education context: an integrated model. Asia Pasific Journal of Marketing and Logistics, 24(5), 755-784.

Romaniuk, J. (2003). Brand attributes: 'Distribution outlets' in the mind. Journal of Marketing Communications, 9(2), 73-92.

Rundle-Thiele, S. \& Mackay, M. M. (2001). Assessing the performance of brand loyalty measures. Journal of Service Marketing, 15(7), 529-546.

Saginova, O. \& Belyansky, V. (2008). Facilitating innovation in higher education in transition economics. International Journal of Educational Management, 22(4), 341-351.
Schreuer, R. (2000). To build brand equity, marketing alone is not enough. Strategy \& Leadership, 28(4), 16-20.

Segoro, W. (2013). The Influence of perceived service quality, mooring factor and relationship quality on customer satisfaction and loyalty. Procedia-Social and Behavioral Sciences, 81, 306-310.

Sharabi, M. (2013). Managing and improving service quality in higher education. International Journal of Quality and Service Sciences, 5(3), 309320.

Shi, Y., Prentice, C., \& He, W. (2014). Lingking service quality, customer satisfaction and loyalty in casinos, does membership matter? International Journal of Hospitality Management, 40, 8191.

Shurville, S., Browne, T., \& Whitaker, M. (2009). Accomodating the newfoung strategic importance of educational technologists within higher education. Campus-Wide Information System, 26(3), 201-231.

Simmons, G., Thomas, B., \& Truong, Y. (2010). Managing i-branding to create brand equity. European Journal of Marketing, 44(9/10), 1260 -1285 .

Till, B. D., Baack, D., \& Waterman, B. (2001). Strategic brand association maps: developing brand insight. Journal of Product \& Brand Management, 20(2), 92-100.

Vazquez, R., Del Rio, A. B., \& Iglesias, V. (2002). Consumer-based brand equity: Development and validation of a measurement instrument. Journal of Marketing Management, 18, 27-48.

Winter, L. C. (1991). Brand equity measures: Some recent advances. Marketing Research, 3, 70-73.

Wood, L. (2000). Brand and brand equity: Definition and management. Management Decision, 38(9), 662-669.

Yeo, R. K. (2008). Servicing service quality in higher education: Quest for excellence. On The Horison, 16(3), 152-161.

Zeithaml, V. A. (1988). Consumer perception of price, quality, and value: A means-end model and syntesis of evidence. Journal of Marketing, $52(3), 2-22$.

Zhang, G., Zhao, Y., \& Lei, J. (2012). Between rock and a hard place: Higher education reform and innovation China. On The Horison, 20(4), 263273. 